\title{
The Epistemology of Maqbul Hadith by Al-Ghazaly
}

\author{
Dr. Jamaludin MA
}

Lecturer Faculty of Islamic Studies, Islamic University of North Sumatera, Medan Indonesia

\begin{abstract}
This research is qualitative research method to interrogate, and express the epistemeology of Maqbul hadith by Al-Ghazaly. Further the method used into this research to analyze descriptive method, and approach used is mustalah al- hadist approach. This research hope able to give contribution, and information to moeslems about maqbul hadith used Al-Ghazaly, and the result of this research is maqbul hadist into Al-Ghazaly's ideas is muttawatir hadist, ahad hadisth, shahih hadith and added with da'if hadith that he found just from some 'alim people.
\end{abstract}

Keywords: Maqbul Hadith, Mardud Hadist, Shahih, and Daif

\section{Introduction}

Islam is one of good religion has perfect moral lesson recovery all human being life aspescts, by relationship with its lord, related to human being with the other human being andrelated to nature. Islam Retile also called by syariat. It is written into Korean taken by a chosen prophet. Although retile called into Korean still global and need meaning suit with Allah , therefore Muhammad Prophet he is a Korean meaning he hang on into sunnah and hadith. With all of sunnah or muhammad prophet hadith is something do not separated with Kor"an. as the word of Allah ;

"O you believe!, obey Allah and obey the Messenger and those in the authority from among you; then if you quarrel about anything, refer it to Allah and the Messenger, if you believe in Allah and the last day; this is better and very good in the end".[Q.S.An-Nisa`:59].

To obey Allah by keep korean, while to obey Rasul by keep sunnah and hadist [Ibn Kaśīr:I:1994:641], is said do or determained and Specific to have to obey Muhammad Prophet as the word of Allah;

"And whatever the Messenger gives your accept it from whatever he forbids you, keep back.[Q.S.Al-Hasyr:7].

The second ayat above to instruction people to keep resourses hadist from Muhammad Prophet. To exest of Hadith is one believeness compulsory we take and we keep. Groups to believe do not need keeping famous hadith with terms destroy as-sunnah mean destroy the second ayat above is a mistake and not good.[MUI: Himpunan Fatwa:2015:25]. All Moeslemees Ulama agree that hadith is source of second law after korean although no all hadith made as law. The Hadith into books account much into classification as global became to maqbul hadith (accepted) and mardud hadith(rejected). Further hadist accepted as law and two shahih hadith, and hasan hadith. While mardud hadith (rejected) is da,if. Maqbul Hadists is Hadith can be made as law according to ulamaes moeslem only shahih hadith and hasan hadith while daif hadith can not be made as argumentation to applied into law problem. In this research will be elaborated about maqbul hadith is hadith can be made as law in says Al-Gazaly.
Al-Gazaly his complete name is Abu Hamid Muhammad ibn Muhammad Al-Ghazaly. (450-505 H). Al-Ghazaly is a Newer in the century of $\mathrm{V} \mathrm{H}$. As be explained with AzZabidi [Az-Zabīdy:I:1989:35]. He is a philosophy moeslem and expert of tassawuf who had known well in the islamic world. He is more famous with the formulation of the book "Ihya Ulum ad-Din which was created in Bagdad, around the year 1105-1107 M. However, if we explore further, actually that Imam Al-Ghazaly is not only a philosopher and exert of tassawuf, but also a mujtahid and jurist (expert of Fiqih) [Ahmad Farid Rifa'i:1936:81].

He explained the results of his ijtihad in the books which discuss about fiqh, such as al-wasit fi al-mazhahb and Ihya ulum ad-Din book which include the problem of fiqih and tassawuf, Although if it is interrogated, actually in the both of the books many found daif hadiths or weak hadiths. Notice in his books al-wasit fit al-Mazhab there are seventy daif hadiths while in Ihya Ulum ad-Din there are twenty three daif hadiths and eight mawdu hadiths (fake-hadists).in the other side, moslem ulamas opine that daif hadith, or mawdu hadist can not be a law. Hadist can be made as a of law it must be daif hadist or hasan hadith.

From a background above writer thinks that it needs to research how actually maqbul hadith theory ( hadist which can be accepted as a law). According to Al-Ghazali. This research exected can give constribution and information to moeslems especially to observer and energizer of islamic law in order to can understand the theory of maqbul hadist which used by Al-Ghazaly which is actually.

\section{Methodology and Source of Data}

This Research is qualitative Research orientated on meaning understanding back or characteristic, Systhematica relation, Conception, value, norm, and abstract understand of formulation is theory used Al-ghazaly to determine that a hadith can be accepted and made a law [Busrowi and Suwandi:2008:20. There is method used in this research is a descriptive method, is express data about theory used $\mathrm{Al}$ Ghazaly to determine one of hadith can be used as a law, then data with use analyze content technic [Moh Nazir:1988:63], is began by analyzing all data provide from some sources. Any method researcher use is approach Mustalah al-Hadist is approach use the regulation 


\section{International Journal of Science and Research (IJSR) ISSN (Online): 2319-7064 \\ Index Copernicus Value (2013): 6.14 | Impact Factor (2015): 6.391}

(constitution) to determine of hadith made as a law according to moeslem ulamae s mayority.

This research is references research, so become research object is Al-Ghazalyes books is al-Mankhul min ta Liqatal Usul, al-Mustafa min 'Ilml al-usul, al- Wasit fy al-Mazhab and Ihya' 'Ulum ad-Din. Besides the books also to research books written by ulama ${ }^{\text {ee }}$ sm mayority of about the regulations maqbul hadith is norm to determine one hadith can be accepted, and made as law such as Taisir Mustalah al-hadist by Mahmud at-Tahan, Tadrib ar Rawy by AsSuyuty,Ulumul Hadist by Dr Nawir Yuslem and the others. The writer of the books as foundation theory to analyze concept of maqbul hadith has formulated by Al-Ghazaly.

\section{Conceptual Framework}

Theory Foundation is very absolute needed in a research, because in a theory foundation the research will has clear foundation to analyze and to clear towards in which problem being research. Suit with title this research about the AlGhazaly maqbul theory hadith, in this research the writer will deliver and emphasize about the definition maqbul hadith, and kind maqbul hadith can made as a law.

\section{Definition of Hadith}

Hadith, according to language, it means khabar, jadid, and qarib near. Khabar mean new, such as delivering by someone to the other. Jadid mean new, against from qadim mean long.[Majma‘ al-Lugah: 1997: 160]. Qarib mean near or yet occur. Any hadith terms definition as a deliver by Dr.Mahmud at- Tahan is:

"All something put to Prophet Muhammad, from says, do, fixed,or attitude.[Mahmud At-Tahan: 1979:14]

From the definition above, so can be understood that hadith any some kinds:

a) Qawly Hadith, is all of hadith said by prohet Muhammad to all purpose and situation, and condition.

b) Fi ${ }^{i e} l y$ Hadith is all do be done by prophet Muhammad.

c) Taqriry Hadith is silent prophet Muhammad from lies says or do to be done him or during he and the matters known. Example taqriry hadith is about agreement prophet Muhammad towards to Muaz ibn Jabal to ijtihad when he does not find dalil from Korean and Hadith towards problems a his proposed him.

\section{Definition of Maqbul Hadith}

Maqbul is isim maf'ul from qabala yaqbalu, maqbul,is accepted,to be agree. Maqbul against is mardud is rejected. And meant with maqbul hadith is hadith into recovery all requirements accepted one hadith. While mardud hadist is all lost hadith or most to be accepted one hadith.

Then mean with maqbul hadith is haditt recovery all requirements maqbul hadith can be made as law dalil. According to moeslem,s ulama mayority, part of maqbul mhost express by Dr.Mahmud at-Tahan is hadith sahih lizatihi, sahih ligairihi, hasan, lizatihi, dan hasan ligairihi.

\section{a. Sahih lizatihi Hadith}

Definition and Classification.
Shahih as language is against from saqim. And while according to terms is knowledge hadith, shahih is:

Hadith go on to sanad, is written by the other, just dabit accepted from all the same(quality) up to sanad no syaz no cillat.['Ajjaj al-Khatib:1989:303]

From definition above can be understood, that hadith can be state shahih has complete five requirements. Some five requirements have formulated by hadith teachers is following:

1) Sanad hadith has to go on. Meant is each man deliver accept of haditt on direct from different people above, From first sanad up final sanad and up to Prophet Muhammad as sources the hadist. Hadiths is not indirect its sanad, can "et be named with hadish shahih, such as hadish munqati, muedal, mueallaq, mudallas the other sanad no direct.

2) People who narrate it have to be an ,alim people, The man who narrate the hadith have to be an ,alim people, moslem, rational, obedient to religion, do not do anything physical, do not do anything that destroy murueah (pride). So justice is an expressio, gathering a few things is moeslem, mukallaf and preventive from causes made a physicaly and cause can destroy person. [Fathurrahman:1970:120].

3) People delivered have to dabit, has correct in received hadith, understand what he hear up time he deliver. or he able to keep hadith in notice from mistakes, exchange and the other can change the hadith. Dabit of a rawi can divided two,is dabit sadran, is strong memory and memorize and, dabit kitaban is tideness written or note.

4) Hadith the deliver do not syaz. Syaz mean the hadith do not break the people more siqat (believe man).

5) The Hadith avoid from ,illat. The definition of ,illat in a hadith, is something which is not clear or hide which can weaken the hadith. A cursory look the hadist is shahih, but if we elaborate more, will be visible defects that damage the hadith. For example munqati hadith (its sanad is broken) stated as a serialized sanad hadith, or mauquf hadith stated as marfu hadith and the other.

Fifth the above requirements is one a barometer to determine the hadith is one hadith shahih. If fifth the requirements fulled, so the hadith named with hadith sahih lizatihi

\section{b. Hadith Sahih Ligairihi}

Hadith Sahih Ligairihi is hadith hasan lizatihi if deliver by way other by same quality and more strong than it.[Mahmud At-Tahan:1979:50]. The hadith named with hadith sahih ligarihi, because to it shahih do not based on its sanad, but based on supported sanad and same posisition with sanad or more strong than it.

\section{c. Hadith Hasan Lizatihi}

According to language hasan is nice, good. And meant with hadith hasan according ibn Hajar is Khabar Ahad delivered by some one ajustice and perfect to its dabit, go on,do not syaz and ,illat that called sahih lizatihi,if dabit less, that called hasan lizatihi.[Ibn Hajar Al-Asqalany:1984:52]. 


\section{International Journal of Science and Research (IJSR) \\ ISSN (Online): 2319-7064 \\ Index Copernicus Value (2013): 6.14 | Impact Factor (2015): 6.391}

With this definition, we can know that lizatihi hasan hadith is a hadith which has completely five requirements of shahih hadith as mention earlier. only difference, on shahih shahih lizatihi hadith, memory of the people who narrated is perfect, but on hasan lizatihi hadith, memory of the people who narrated is almost perfect.

Hadith hasan Ligairihi

Hadith Hasan Ligairihi is hadist da eeif (weak),if way more than one,and cause weaked no cause is deliver cheat oe lies. [Mahmud At-Tahan:1979:51].

Fourth kinds of hadith is maqbul hadist can be made as law dalil according ulama mayority. Other four kinds hadith above, is hadist daif don ${ }^{\text {ee }}$ have any requirements as sahih lizathi, shahih ligairihi, hasan lizatihi and hasan ligairihi, so classification as mardudu hadith (rejected) and can ${ }^{e e} t$ be able as law dalil

\section{Result and Discussion}

AS Al-Ghazaly moeslem es ulama mayority can be replaced as the second hadith law sources after Koran. If view from perawi account, so Al-Ghazaly divided the hadith into 2 kinds, are:

\section{Mutawatir Hadith}

Mutawatir as a language is isim fail from tawatur meant attatabu' is suit. ccording to the terms hadithee $\mathrm{s}$ ulama, muttawatir is hadith delivered by many people according to their tradition imposible do sin. [Mahmud AtTahan:1979:18].

Al-Ghazaly does not give definition about muttawatir hadith but he delivered four requirements have to complete muttawatir hadith is:

a) Delivered based on believeness, no assumption.[AlGazaly: II: t.t: 138]

b) New right taken based on five body enough requirements, part rawi accout on a level, if ulama khalaf delivered from ulama salaf, during together but requirements do not fulled each different generation with other generation.

c) Standard of Minimum Narrator of Hadith

Al-Ghazaly in mutawatir hadist problem doesn't determine the ammount of minimum narrator of hadith that is used as requirements, but the hadist must be narrated by many people and based on the tradition impossible that they can lie. [Al-Gazaly: II: t.t: 138]

From description above can be concluded that mutawwatir hadith according Al-Ghazaly is hadith is delivered by many people on their custom believed impossible to agree to do lies. Al- Ghazaly doesn"t determine rawi account, but enough if the hadith delivered by many people, and believed their do not to agree to do lies, so hadist called with muttawatir hadith.

\section{Ahad Hadith}

Ahad word is many from one is one. Khabar wahid is khabar delivered by one person.
Al-Ghazaly gives definition ahad hadith, know that we meant with khabar ahad into this spoke is hadith not until degree mutawatir hadith the result believeness. [Al-Gazaly: II: t.t: 145]

Hadith which delivered by five or six person is included into ahad hadith. As for practicing ahad hadith is an obligation because there is sure dalil which requires practice when there is zan (supposition) that toward to rightness. AlGhazaly says that ahad hadith can be practiced.

In moeslem khazanah many hadith spread more than less one hundred books contents hadists- rasullulah saw, although no all can made as hujjah or dalil into fixed one law. Moeslem teachers has choosen which hadith accepted as law dalil and rejected. In Hadith knowledge terms there are maqbul hadith(accepted) and hadith mardud(rejected) the following this research say maqbul theory hadist according Al-Ghazaly view:

Classification hadits according to Al-Ghazaly can made became 3 big descriptions is:

1) Hadith have to accepted rightness (mayajibu tasdiqu), form hadith taken for granted is:

a) Khabar delivered by people number as a tawatur although it ${ }^{\text {ee }}$ no other dalil to show rightness and muttawatir hadist has enough four requirements called. Al-Ghazaly ees theory according to written same by jumhur ulama receive muttawatir hadist as law dalil no need again research sanad hadith. Muttawatir hadith give advantage darury knowledge,all muttawatir hadist is maqbul hadist obligate accepted and keep.[Nawir Yuslem:2001:207].

b) Khabar from of Allah delivered to prophet Muhammad. In terminology knowledge hadith, called by qudsy hadith, Qudsy hadith is something delivered Allah to it prophet by ilham and dreamed, then a prophet delivered meaning from ilham or dreamed by expression or his own.

c) Khabar from prophet Muhammad. Prophet Muhammad is human being a honest and do not imposible receive mukjizat if he lier man. Khabar from Prophet Muhammad do not out from status as take risalah to delivered to moeslem is Alquran and Hadith.

d) Khabar take by many people, because this matters has explain by prophet Muhammad that many people do not lies.but not that their guaranteed honestly prophet Muhammad and Allah.

e) Each Khabar suit word of Allah and hadist to the moeslem accepted on logically.

f) Each Khabar delivered to prophet Muhammad, he hear, he forgotten and he silent. If the news lies of course prophet Muhammad do not silent, in terms of hadist knowledge it "s called by taqryry hadist. Is silent prophet Muhammad from lies says and do to be done him during he and matters known.

g) Each Khabar has agree by jamaah groups, while according the tradition, if occur new lies their not silent, Hadith has keep by groups together, although the hadith da, if according to hadith knowledge, Al- Ghazaly receive as law argument.

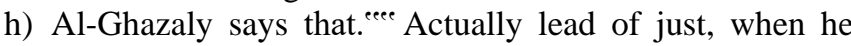
says that prophet Muhammad has says has delivered mea siqah, so hadith can be accepted.[Al-Gazaly:274] Hadiths 


\section{International Journal of Science and Research (IJSR) \\ ISSN (Online): 2319-7064 \\ Index Copernicus Value (2013): 6.14 | Impact Factor (2015): 6.391}

accepted from siqah, Al-Gazaly do not held this research again, because a siqah do not lies. So the hadith daif according terminology hadith knowledge, he use as law argument. Al-Ghazaly do ijtihad, no hadist sahih made law, but has finished of hadist to daif hadith guide AlGhazaly is, when delivered the hadith is just or siqah man, so hadist made as law hadith.

2) Hadith known lier ( ma yu' lamu kazibuhu). Form the hadith recovery

a) Hadith against with logic, well think, five body in fact or tawatur khabar.

b) Hadith against with nas suit, is Korean, mutawatir hadis and moeslem ijma.

c) Hadith rejected by many people, impossible custom their do lier.

d) Hadith do not delivered by many people.

3. Hadith isn't known rightness or lier ( ma la yu' lamu sidquhu wa la kizbuhu) is number of hadith releated with syara, law and worship it "no known right or no so there are any clean. The argument like this for us to tawaqquf. So AlGhazaly comment, Hadith it, no known rightness or lier ma, ist la yu lamu sidquhu) is hadist against between one hadist it"no keep. Hadiths against Al-Ghazaly has given solution with do al-jam 'u wa at taufiq, and if no probably, and the second do nasikh mansukh, and the third with do tarjih. Into al-Mankhul he says the steps tarjih,is:

1) To deep nasikh and mansukh

2) To choose hadist a rawy more siqah

3) To choose perawi much more

4) To choose hadith, supported by experience friend ${ }^{\text {ee }} \mathrm{s}$ prophet Muhammad

5) To choose hadith, supported by experience tabi'y

6) To choose hadith, supported by Kor ${ }^{\text {ee }}$ an

7) To choose hadist supported by qiyas

8) To choose hadith, supported by ihtiyat

9) To Choose a hadith, content sentence isbat from content sentence.

If the steps have done, also can't be done tarjih, so please tawaquf. (no keep the second hadith against). The teory says Al-Ghazaly different with syafi'yah groups and malikiyah opinion effort it second al-jamuwaat-taufiq, then if the way can't be done, so made the second way, is nasikh mansukh, then tawaquf. [Nasrun Haroen:1997:178]

After analyzing, expressions has stated by Al-Ghazaly can be understood that maqbul hadith is:

1. Mutawatir Hadith, is hadist to be keept by many people and based on logically or customs, their imposible will be agreed to do lier. Definition mutawatir hadith according Alghazaly and teachers majority no different and also about opinion, that mutawatir hadith is maqbul hadith to be keep obligation.

2. Other muttawatir hadith, is ahad hadith to keept obligation, he gives the requirements, that to deliver the hadith have to mukallap, just dabit and moslem. And other requirements as stated by teachers mayority, such as muttasil, no syaz and no berilliat, Al-Ahazaly it no mentioned.
Muttasil means is that each people delivered receive hadith direct from perawi on it. From sanad up to final sanad and go on up to Muhammad Prophet as hadith source. Further the hadith broken sanad, such as munqati hadist, mu'dal, muallaq, mudallas and the other maqbul hadist according Al-Ghazaly different with ulama, hadith it no go on, it no shahih and no entry maqbul hadith. Theory stated by AlGhazaly express very easy, because do not requirements between the people delivered meet or one during with on. But mos although"eAll the people to delivered have to prove with research of biografi and the people to delivered the hadith. Their fact never the hadith made as law argument.

Syaz meant against with against the other against more strong or more siqah. see to syaz definition above, can be understood that hadist isn ${ }^{e} t$ syaz is hadist the content hadith no against with the other more strong or more siqah.

' Illat or bad is hadith appear shahih on first view, but when studied on becarefully found factors can cancelled it shahih the factor such as, stated musnad hadith but mursal, marfu but it is mawquf. a perawi delivered a hadith from a syeikh, actually he never meet with the syeikh. He put a hadith to a friends. bad can occur on isnad or matan (content) hadist.

So in requirements maqbul hadith Al-Ghazaly do not requirements there are any berilliat. According to teachers majority, hadiths it "eno full requirements, is delivered by just people, dabit, muttasil, do syaz and don't beriliat, so the hadith part daif hadith and can not made law argument. So Requirements maqbul hadith delivered by Al-Ghazaly more easy if compare with opinion "es ulama mayority, so ahad maqbul hadist according to Ghazaly is shahih hadis, and da if hadith.

3. Hadith received by just people and siqah and hadis has permitted and keep by group people, hadith received by just people and siqah, and hadith has keep by one people, he does not hold this research, because to assumption that just people and siqah or one jamaah or probably do lier.

Al-Ghazaly is an arrangement and the author ${ }^{\text {ee }}$ m much analyze tasawuf problem, fiqih, tauhid, akhlak. Althought tasawuf is a knowledge dominant has characteristices tasawuf moslem cannonist no as a hadist.of course this amplication that each hadist delivered an just people an a siqah or hadist came from his assumption he is honest and made as law argument. Hadith point according to a sufi glasses honest supposition that each hadist up to came from prophet Muhammad and all deliver hadist up to as hadith received.

It can be read by written into al-Mustafa min 'ilml al-Usul to short but has large is „Obligation, we receive just man, although isn one day do lier and mistake.'[Al-Gazaly: AlMustafa:II:233]

Into hadith delivered to Al-Gazaly. To just people, although in the hadist or someone or some people Or some mastur (hide) then mazhul. This matters Al-Ghazaly do not research again, because the people delivered to the judge. 


\section{International Journal of Science and Research (IJSR) \\ ISSN (Online): 2319-7064 \\ Index Copernicus Value (2013): 6.14 | Impact Factor (2015): 6.391}

The Ghazalyees attitudes is suit, because he deep in tassawuf part to effort to hold this approista to Allah. He does not research a hadist has suit point in hadist Al- Ghazaly ${ }^{\text {ee }}$ s book ever says in books Jawahir al-Qur'an that not much to knowledge mastry ${ }^{\text {ee }}$ hadith.[Imam al-Gazaly: Ilmu dalam Perspektif Tasawuf al-Gazali:5-8].

example

\section{Order to joint heirs}

On Principly of wasyiat to the joint heirs may not permitted, because he has part particularly as hadith, although if the joint heirs permitted, wasyiat to joint heirs permitted, because any hadith :mean from ibn abbas has says prophet Muhammad so .no permitted wasyiat to the joint heirs except ahli waris to permitted except the other joint heirs permitted

Al-Ghazaly ${ }^{\text {ee }}$ opinion different with ulamaes mayority no permitted wasyiat to the joint heirs. Ahli waris has part to determined. some arguments ulamaes mayority about may not give prosperous to the ahli waris five hadis except, Nasa $i$ is "from Aby Umamah, has says, I have heard prophet Muhammad said, actually Allah has given each people have right $s$ it ${ }^{e c}$ no to joint heirs.

This Hadith part of hasan hadith made dalil may not give wasyiat to joint heirs. This hadith also nasakh (law lost) ayat one hundred and eigty surat al-Baqarah is:

"Bequest is prescribed for you when death approaches one of you, if he leaves behind welth for perents and near relatives, according to usage, a duty (incumbent) upon those who guard (against evil).(Q.S.Al-Baqarah/2:180).

\section{Nisfu Syaban Have pray}

Al-Ghazaly in his books Ihya' 'Ulum ad-Din says that do have pray on nisfu sya'ban night and rajab night is sunnat. Nisfu Syaban his opinion that there are thirty persons do as delevered from al hasan that he says : has informed me thirty students prophet Muhammad, actually what do have pray on this night (Nisfu Syaban) Allah sight with seventy sighting, and Allah finished each one time with seventy kinds need, law find lovely. (Al-Gazaly: Ihya’, I: 203)

Ulamaes mayority says that hadist above is daif hadith and don ${ }^{\text {et }}$ made as argumentation to fixed one law. Ibn al-jauzy into Kitab al-Maudu'at says that hadiths related to pray of nisfu syaban night is hadith maudu' (false hadist).

Imam Nawawi is ulama syafie $i$ es mazhab says that is one ulama which syafiei mazhab says that have pray rajab and nisfu sya'ban is bid'ah and bad. As to express the following:" famous is ar -ragaib salat is pray twelve rakaat done between magrib and isya` first friday month rajab and have pray Nisfu syaban one hundred rakaat, the second is do bid'ah which mad and bad.(An-Nawawi:Majmu':III:125126).

Muhammad Syata`ad- Dimyaty into his books I'anah atTalibin and says: part from do and bad, sin from doer and ulil amri to obligation is have day and ar-ragaib is have pray twelve rakaeat done between magrib and isya`. First friday month rajab and pray Nisfu Syaban one hundred raka'at and seventeen friday month ramadan with express to change have pray asyura day four rakaat are heresy (bid,,ah).

\section{Conclusion}

Al-Ghazaly is a syafie $i$ mazhab as great mujtahid. As also ulamaees mayority ulama Al-Gazali sight that hadist is law . The second kor'an. Although the theory or method and the hadith made law dalil according to al-Ghazaly (maqbul) is muttawatir hadith, shahih hadith, hasan and also take da' $\mathrm{f}$ hadith, during the hadist received deliverd just people.

\section{References}

[1] Alquran

[2] Amin, Kamaruddin, Dr, Menguji Kembali Keakuratan Metode Kritik Hadis, Jakarta: Hikmah PT Mizan Publika, 2009

[3] Atabik Ali dan Ahmad Zuhdi Muhdlor, Kamus Komtemporer Arab - Indonesia, Yokyakarta: Multi Karya Grafika, 1998

[4] Al-'Asqalāny, Ibn Hajar, Syarh Nuhbah al-Fikr fì Mustalah al-Hadìs, Kairo: T.t.p, 198

[5] Basrowi dan Suwandi, Memahami Penelitian Kualitatif , Jakarta: Rineka Cipta, 2008

[6] Al-Gazāly, Abū Hāmid Muhammad bin Muhammad, Mukāsyifah al-Qulūb, t.t.p:Dār al-Fikr,t.t

[7] Al-Gazāly, Abū Hāmid Muhammad bin Muhammad, Ilmu dalam Persepektif Tasawuf al-Gazali, terj.Muhammad al-Baqir, Bandung: Penerbit Karisma, 1996

[8] -------------, Abū Hāmid Muhammad bin Muhammad, al-Mustasfā min `Ilm al-Usūl, ed: Dr Hamzah bin Zahīr Hāfiz, Madinah al-Munawwrah: T.t.p, t.t

[9] ------------, Abu Hāmid Muḥammad bin Muḥammad bin Muhammad, Ihyā' 'Ūlūm ad-Dīn, Beirut: Dār alFikr, 1992/1412

[10]-------------. Abū Hāmid Muhammad bin Muhammad, al-Wasīt fy al-Mazhab, T.t.p: Dār as-Salām, 1997/1417

[11] -------------, Abu Hamid Muhammad bin Muhammad alGazālī, al-Mankhūl min Ta 'līqāt al-Usul, T.t.: t.p, t.t

[12] Haroen, Nasrun, Dr, Usul Fiqh I (Jakarta: PT Logos Wacana Ilmu, 1997

[13] Ibn Kaśīr, al-Fidā' al-Hāfiz, Tafsīr al-Qur 'ān al- 'Azīm, Beirut: Dār al-Fikr, 1994/1414

[14] Al-Jauzy, Aby al-Farj 'Abd ar-Rahman bin 'Aly bin, Kitāb al-Maudu 'āt,Beirut: Dār al-Fikr, 1983

[15] Krippendorff, Klaus, Analisis Isi Pengantar Teori dan Metodologi, Terj Farid Wajidi, Jakarta:Rajawali Pers, 1991

[16]Al-Khatīb, Muhammad `Ajjāj, Dr, Usūl al-Hadīs 'Ilūmuhu wa Mustalahuhu, Beirut: Dār al-Fikr, 1989

[17]Majma` al-Lugah al-`Arabiyah, al-Mu jam alWasīt,India: Kutub Khānah, 1997

[18] An-Nawawy, Muhȳ̄ ad-Dīn Yahyā bin Syaraf, Kitāb alMajmū, Jedah : Maktabah al-Irsyād, t.t

[19] Majelis Ulama Indonesia, Himpunan Fatwa MUI, Jakarta: Penerbit Erlangga, 2015

[20] Nazir, Moh, Dr, Metode Penelitian, Jakarta:Ghalia Indonesia, 1988

[21] Rahman, Fatchur, Drs, Ikhtisar Mushthalahul Hadis, Bandung: PT Alma`arif, 1970 


\section{International Journal of Science and Research (IJSR) \\ ISSN (Online): 2319-7064}

Index Copernicus Value (2013): 6.14 | Impact Factor (2015): 6.391

[22] Rifā,,̄i, Ahmad Farīd, Silsilah Zu'amā’al-Falsafah wa al-Adab wa al-Akhlāq Halqah al-Gazālī, 4 Mesir: „Īāa al-Bāb al-Halabī,1936

[23] Suparta, Munzier,Dr, Ilmu Hadis, Jakarta: PT Raja Grafindo Persada, 2002

[24] Sayyid Sābiq, Fiqh as-Sunnah, Beirut: Dār al-Fikr, 1983

[25] At-Tahān, Mahmūd, Taisir Mustalah al-Hadīś, Beirut: Dār al-Qur’ān al-Karīm, 1979

[26] Wajdī, Muhammad Farīd, Dā irah Ma 'ārif al-Qarn al'Isyrīn, Beirut:Dār al-Ma ,rifah, 1971

[27] Yuslem, Nawir, Dr, Ulumul Hadis, Jakarta: PT Mutiara Sumber Widya, 2001

[28] Az-Zabīīi, Muhammad ibn Muhammad al-Husain̄̄, Ittihāf as-Sādah al-Muttaqīn, Beirut:Dār al-Kutub al„Ilmiyah, 1989

\section{Author Profle}

Dr Jamaluddin MA is a Lecturer Faculty of Islamic Studies, Islamic University of North Sumatera Medan Indonesia, he was born on 23 March 1958. He graduated and got degree Sarjana Muda (BA) in major Qada in 1982 in Islamic University of North Sumatera. And then he continued his bachelor in Faculty of syariah in major "Perbandingan Mazhab \& Hukum IAIN north Sumatera in 1987. His magister in major "Pengkajian Islam" in 2005 and his doctor in major "Hukum Islam" in 2012 in IAIN also. 